\title{
THE ROLE OF ENVIRONMENT IN STIMULATING THE DEVELOPMENT OF GREEN ECONOMY
}

Katarzyn Brodzinska ${ }^{1}$, PhD habilitated; Zbigniew Brodzinski ${ }^{2}$, PhD habilitated ${ }^{1}$ Department of Agrotechnology, Agricultural Production Management and Agribusiness, University of Warmia and Mazury in Olsztyn, Poland; ${ }^{2}$ Department of Sgpatial and Environmental Economics, University of Warmia and Mazury in Olsztyn, Poland

\begin{abstract}
In terms of supporting the development of green economy, it is important to understand the role of environment in stimulating its development. The results of an empirical study conducted in 2017 on a randomly selected sample of 578 enterprises of the SME sector, directly related to green economy, indicated that not only macroenvironment (the policy pursued, the creation of global institutional solutions supporting the development of resource-efficient technologies) but also meso- and microenvironment affected the development of green economy. A major role in this regard is served by the activity of local government units and by the activities of non-governmental organisations that form the institutional environment of enterprises. These institutions have tools and instruments, which they can use to stimulate the process of "greening" of the local economy.
\end{abstract}

Key words: green economy, enterprise, environment, development.

JEL code: R11, R58

\section{Introduction}

For the majority of Polish society, green economy is a completely new idea, both in terms of regulations that support its development and of practical effects of the implementation of technologies and organisational solutions aimed at the protection of natural environment (Kryk, 2011; Gorka, Luszczyk, 2014; Prospect for ..., 2017). The concept of green economy is inextricably linked to the paradigm of sustainable socio-economic development, based on three attributes i.e. low-emission performance, resource efficiency, and social inclusion (Cato, 2009; Adapting for ..., 2011; Brand, 2012).

The implementation of measures conducive to the development of green branches of economy and green jobs is encouraged by international organisations including OECD ${ }^{1}$ and the European Union $^{2}$. At the local level, the idea in question is supported by the measures taken by numerous non-governmental organisations and public institutions.

Given that enterprises operate within a specific external environment, this environment provides them with certain opportunities and possibilities while imposing requirements and restrictions on them. The group of factors which affect the rate of development of, generally, all enterprises, includes inter alia fiscal policy of the state, legal mechanisms and regulations concerning the freedom to conduct a business, the level of economic growth, economic conditions, availability of loans and lending rates, demand and supply of qualified workforce, and employment regulations. As regards the entities representing the broadly understood sphere of green economy, important issues include: the level of support for activities related inter alia to the development and implementation of environmentally-friendly products and services, the rate of implementation of pro-environmental investment projects (including as part of public procurement) ${ }^{3}$, the scope and scale of preferences for green economy entities and sectors, and the level of social awareness (Szyja, 2015). In terms of searching for the possibilities for supporting the development of green

\footnotetext{
${ }^{1}$ Green Growth Indicators 2014. OECD Green Growth Studies, OECD, Paris 2014, http://www.keepeek.com/Digital-AssetManagement/oecd/environment/green-growth-indicators2013_9789264202030-en (accessed on 02 December 2017).

2 The Employment Package prepared by the Commission in 2012 presents the framework for job-rich recovery, emphasising the need for the further development of labour market tools and the identification of demand for skills in order to support both the transition to green economy and the progress in meeting the employment objectives defined in the Europe 2020 strategy.

${ }_{3}^{3}$ Pursuant to EU regulations, Poland is obliged to take actions concerning low-emission and resource-efficient economy (Low-Emission Poland 2050 project, the National Programme for the Development of a Low-Emission Economy). 
economy, it is of importance to identify the factors determining its development, including primarily the understanding of the role of environment.

From the research perspective, the effects of green economy on the development of sectors and regions are interesting, therefore the research area was selected to be Warmia and Mazury Voivodeship i.e. a region unique in terms of environmental values. Two main geographical lands, namely Warmia and Mazury also referred to as "The Land of One Thousand Lakes", are an area in which the development of green economy should be particularly stimulated. In order to assess the measures taken in this regard, a study using the interview method and the CATI (Computer Assisted Telephone Interviewing) technology was conducted in 2017 on 578 randomly selected enterprises of the SME sector, directly related to green economy, including those involved in agrifood processing, provision of services, production, and rural tourism. Even though, in sectoral terms, green economy most frequently concerns the sectors connected with renewable energy sources, environmentally-friendly construction materials and energy-efficient construction, environmentally-friendly transport, water and waste management, and spatial management (Ayres, 2010), the main criterion for distinguishing it is the combination of environmental and social aspects (Ryszawska, 2013). The aim of the research is to know the determinants of the development of green economy. The tasks of the research include analysis of local environment of green economy indicates by subregions (NUTS 3 ) and the areas of economic activity of enterprises.

\section{Research results and discussion}

\section{Environment as a determinant of the development of enterprises}

The source literature provides many various methods for identifying and assessing the role of environment in stimulating the development of enterprises (Institutional environment ..., 1999; Walczak, 2010; Jablonski, Jablonski, 2012; Wasilczuk, 2015; Prospects for ..., 2017). The environment of enterprises, including those operating in green economy sectors, is formed by the elements and participants of the market that affect their activities (Flak, Glod, 2009; Rachwal, 2011). This environment is comprised of both the macroenvironment i.e. elements that are external in relation to the enterprise (e.g. technical, economic, social, demographic, political, legal, and cultural determinants) and which are not affected by the enterprise, and meso- and microenvironment which may be, to a certain extent, affected by the enterprise.

One of the major features of the environment is its variability and complexity, the strength of the influence on a particular organisation or processes (North, 1990; Hwang, Powell, 2005; Limanski, 2015). This is the complexity and uncertainty of the environment that have an effect on the process of the development and implementation of an enterprise's strategy, and thus on the structure of the instruments and actions applied. In this context, considerations concerning the possibilities for the development of enterprises of the green economy sector can be focused on searching for factors - both those having a direct effect on its operation and development and those affecting its environment indirectly. Practice shows that entrepreneurs pay more and more attention to factors related to the environment. Based on observations and analyses, it can be assumed that such an attitude in business thinking and acting is a consequence of the increase in importance of network and project organisations in which the boundaries between the enterprises and the environment are very flexible (Krupski et al., 2009).

What is also important is the issue of globalisation of the economy, which is conducive to the formation of strong economic groups stimulating the activity of enterprises (e.g. support as part of 
EU programmes). Such a situation supports the efforts to disseminate the cooperative approach based on the idea of cooperation in market activities (Fayerweather, 2007).

Another important issue is the relationships of enterprises with the sphere of research and development, since the development is more and more dependent on the ability to acquire financial support for projects implemented commonly with entities present in the environment of the firm.

Against the background of economic tendencies and trends characterising modern carrying on of an enterprise, a question arises about the way of developing relationships with the environment and of creating conditions that enable making use of the environment for the operation and development of business entities.

\section{Environment as a factor of the development of green economy - an empirical study results}

The source literature provides numerous classifications of regional determinants. The regional environment comprises public administration units, funding institutions, scientific and educational institutions, and service infrastructure institutions supporting the development of entrepreneurship and conduct of business activities (Wach, 2008). Institutions of the public sphere are particularly responsible for creating local conditions for the development of entrepreneurship, including for the state of technical infrastructure (roads, sewerage, water supply), the level of safety, the situation in the labour market, activity of non-governmental organisations, and entrepreneurship of inhabitants. Another factor affecting the rate of changes in the economy is the local government units' activities oriented towards the activation of the local community through creating a friendly climate for the development of entrepreneurship initiatives, supporting the process of job creation but also maintaining new jobs, particularly in environmentally-friendly sectors, attracting new investors, strengthening local economy through the establishment of connection networks, raising the level of infrastructure in the area etc. (Filipiak, Ruszala, 2009).

According to the adopted assumption, understanding the determinants of the development of green economy was based on measures that enable the identification of local problems for general groups and factors. The assessment of conditions provided to economic entities by the institutional environment can be assisted by the use of the following subjective component grades for such spheres of socio-economic life, as:

- the state of the natural environment,

- living and accommodation conditions,

- access to information and knowledge on local environment and its problems,

- the quality of technical infrastructure (e.g. roads, sewerage, water supply),

- the situation in local labour market,

- the efficiency and scale of activities of non-governmental organisations,

- the activity of local governments in stimulating the development of SME sector.

An analysis of the obtained opinions of entrepreneurs, concerning the assessment of the elements of local environment of green economy indicates that this is the state of the natural environment that has the strongest effect on the potential for the development of the "green sector" (47.4 pp). In turn, on the regional scale (NUTS 2), the major barrier to the development of green economy is the situation in the labour market (-1.9 pp). However, it is worth emphasising the role of local determinants in stimulating the development of green economy, which is already noticeable at the subregion level (NUTS 3), (Fig 1). 


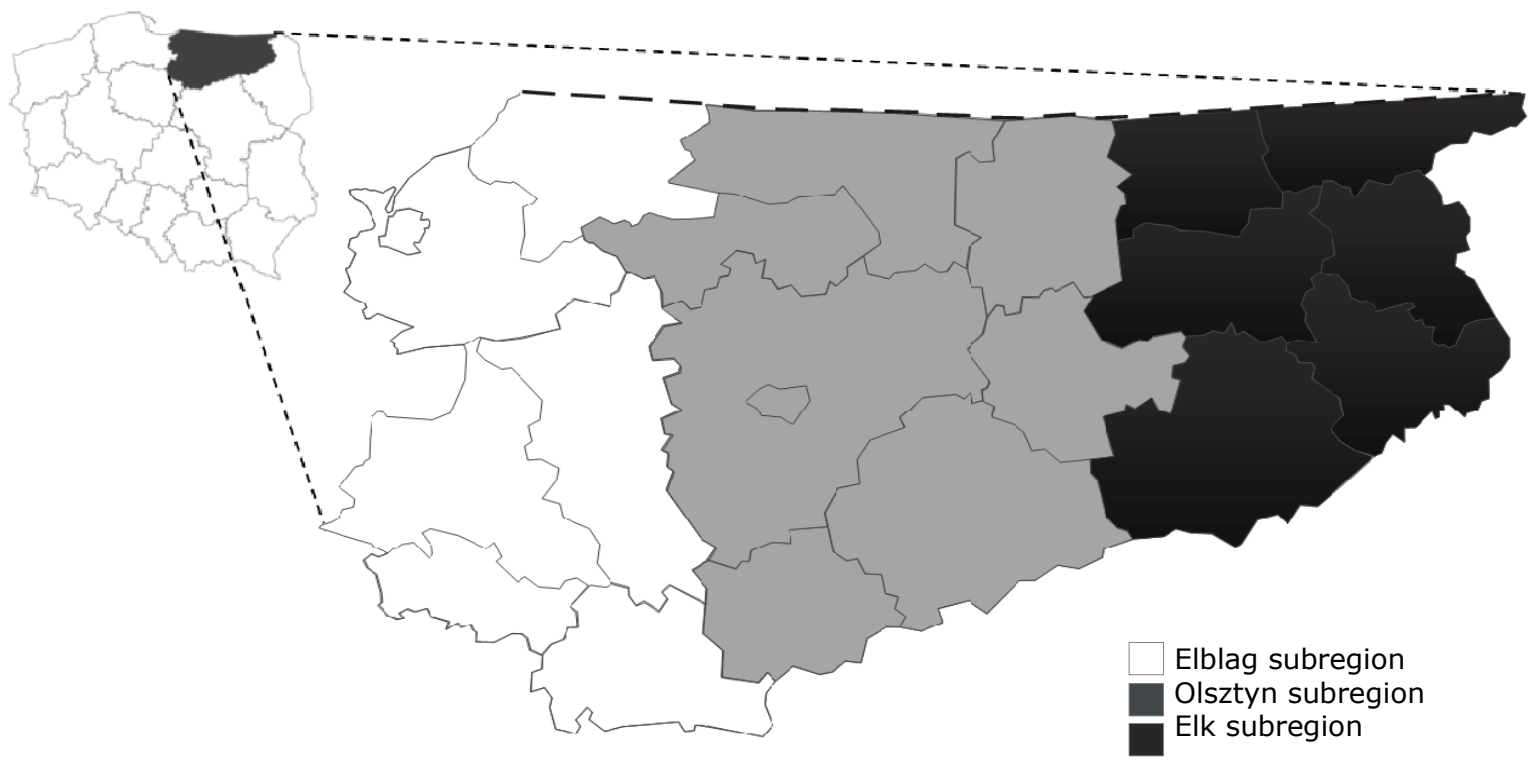

Fig. 1. Differentiation of local determinants in stimulating the development of green economy

In the subregion of the city of Olsztyn, the state of the natural environment was rated the highest by entrepreneurs, while in the subregion of the city of Elk, the highest rated ones were the environment factors associated with the activity of local governments and non-governmental organisations. Therefore, the conditions of the local environment of green economy are most favourable in the Elk subregion (Table 1), and not only do they result from environmental determinants but primarily from the skills of making use of the available tools and instruments in the process of the so-called "greening" of the economy.

The balance of ratings of local factors forming the environment of green

Table 1 economy, broken down by subregions

\begin{tabular}{|c|c|c|c|c|}
\hline \multirow{3}{*}{ Specification } & \multirow{2}{*}{ Total } & \multicolumn{3}{|c|}{ Subregion } \\
\hline & & Elblag & Olsztyn & Elk \\
\hline & \multicolumn{4}{|c|}{ The balance of pp1 } \\
\hline The state of the natural environment & 47.4 & 19.3 & 66.9 & 56.6 \\
\hline Living and accommodation conditions & 33.2 & 19.4 & 37.4 & 49.6 \\
\hline Access to information & 32.4 & 21.2 & 27.1 & 64.4 \\
\hline The quality of technical infrastructure & 18.7 & 15.1 & 12.8 & 38.2 \\
\hline Situation in the labour market & -1.9 & 13.3 & -30.7 & 33.0 \\
\hline $\begin{array}{l}\text { The efficiency and scale of activities of non-governmental } \\
\text { organisations }\end{array}$ & 28.2 & 17.0 & 28.3 & 48.7 \\
\hline $\begin{array}{l}\text { The activity of local governments in stimulating the development of } \\
\text { SME sector }\end{array}$ & 27.1 & 15.1 & 26.3 & 51.4 \\
\hline
\end{tabular}

Source: authors' calculations based on own research.

An analysis of local elements of green economy environment in rural areas of Warmia and Mazury Voivodeship demonstrated that the major barrier which is virtually independent of the area of economic activity of the enterprises under study (production, tourism, agri-food processing) is the difficult situation in the labour market. Even though according to the assessment carried out by representatives of service-providing enterprises participating in the study, the balance of ratings

${ }^{1}$ The effects of particular factors were assessed as definitely unfavourable, unfavourable, neutral, favourable, and very favourable. The balance of pp is the difference between the sum of favourable and very favourable ratings and the sum of unfavourable and definitely unfavourable ones, expressed in \% of responses. Negative values indicate that in the respondents' opinions the particular factor of the environment restricts the possibilities for the development of green economy, and a high value of the balance indicates that the particular factor is perceived as a development stimulator. 
for this factor took a negative value, this index reached a very low value (1.8 pp), which means that the labour market is the area that does not create a strong potential for the development of green economy in Warmia and Mazury Voivodeship.

The causes of the occurrence of problems in the local environment of enterprises belonging to the green sector of economy in rural areas of Warmia and Mazury Voivodeship are not only related to the unfavourable situation in the labour market and unemployment (opinions of $50.8 \%$ respondents) but also with the unfavourable situation in agriculture $(25.4 \%)$ and with the low level of entrepreneurship development (23.3\%); these problems are accompanied by the lack of possibilities for acquiring capital (22.8\%) as well as a low standard of living of rural inhabitants $(14.6 \%)$. What is more, in the opinions of entrepreneurs representing the agri-food processing sector, besides the situation in the labour market, the situation in agriculture and the potential possibilities for acquiring capital are of significance. On the other hand, in the opinions of representatives of firms operating in the tourism sector, the problems related to the standard of living of rural inhabitants and to the way the local government units are managed are more important (Table 2).

\section{The most important groups of problems restricting the development of green economy, broken down by the areas of economic activity of enterprises ( $\%$ of respondents)}

\begin{tabular}{|l|c|c|c|c|c|}
\hline \multicolumn{1}{|c|}{ Specification } & \multirow{2}{*}{ Total } & \multicolumn{2}{c|}{ Areas of economic activity of enterprises } \\
\cline { 3 - 6 } & & $\begin{array}{c}\text { Agri-food } \\
\text { processing }\end{array}$ & $\begin{array}{c}\text { Service- } \\
\text { providing }\end{array}$ & Production & Tourism \\
\hline $\begin{array}{l}\text { Situation in the labour market and } \\
\text { unemployment }\end{array}$ & 50.8 & 61.5 & 52.1 & 50.4 & 42.1 \\
\hline $\begin{array}{l}\text { The unfavourable situation in } \\
\text { agriculture }\end{array}$ & 25.4 & 61.5 & 29.1 & 19.5 & 2.6 \\
\hline $\begin{array}{l}\text { The low level of entrepreneurship } \\
\text { development }\end{array}$ & 23.3 & 23.1 & 24.7 & \multirow{2}{*}{16.3} & 13.2 \\
\hline $\begin{array}{l}\text { The lack of possibilities for acquiring } \\
\text { capital }\end{array}$ & 22.8 & 38.5 & 23.6 & 17.1 & 21.1 \\
\hline $\begin{array}{l}\text { Low standard of living of rural } \\
\text { inhabitants }\end{array}$ & 14.6 & 0.0 & 14.7 & 15.4 & 15.8 \\
\hline Social pathologies & 10.1 & 7.7 & 11.9 & 4.9 & 5.3 \\
\hline $\begin{array}{l}\text { Bad condition of technical } \\
\text { infrastructure }\end{array}$ & 9.4 & 15.4 & 9.1 & 8.1 & 10.5 \\
\hline Peripheral location & 1.6 & 0.0 & 1.9 & 1.6 & 0.0 \\
\hline The way the local government units & 1.2 & 0.0 & 0.6 & 2.4 & 5.3 \\
\hline
\end{tabular}

Source: authors' calculations based on own research

\section{Conclusions, proposals, recommendations}

The environment in which modern enterprises operate is becoming increasingly complex and variable while serving an important role in stimulating the socio-economic development of the region. The scope of connections between enterprises and the environment is constantly expanding, and not only relates to the technical or economic sphere but also extends to include the sphere of social, political, and cultural issues. Due to the high volatility of the environment in which enterprises operate, and to the complexity of relations, an enterprise which intends to survive in the market and to maintain the competitive advantage needs to adjust to changes in the environment. The need to take appropriate adaptation decisions changes the scope, methodology, and the logic of the operation of an enterprise. 
The research indicates that the "greening" of the economy is, to a large extent, dependent on the local and regional determinants. The assumptions of the concept of development, including of green economy, are most frequently made, in terms of planning and the programme, at the level of international organisations (EU), and are implemented as part of national programmes. However, this is the activity of local government units, the efficiency of non-governmental organisations, the involvement of entrepreneurs, and the attitudes of local communities that determine the effects of these actions.

\section{Bibliography}

1. Adapting for a Green Economy: Companies, Communities and Climate Change (2011). UN Global Compact, UN Environment Programme, Oxfam, World Resources Institute http://pdf.wri.org/adapting_for_a_green_economy.pdf Access: 29.01.2018.

2. Ayres, R., van der Lugt, C. (2011). Manufacturing. Investing in Energy and Resource Efficiency. In "Green Economy Report, Towards a Green Economy: Pathways to Sustainable Development and Poverty Eradication", UNEP.

3. Brand, U. (2012). Green Economy - the Next Oxymoron? No Lessons Learned from Failures of Implementing Sustainable Development, GAIA, vol. 21, No 1. pp. 28-35.

4. Brodzinski, Z., Brodzinska, K., Borawska, M., Borawski, P., Kurowska, K., Pawlewicz, A., Sledz, D., Tomczyk, U. (2017). Perspektywy rozwoju zielonych miejsc pracy w woj. warminsko-mazurskim. (Prospects for the development of green jobs in the Warmia and Mazury voivodeship) (2017). ed. K. Brodzinska, Z. Brodzinski. Wyd. New Europe, Olsztyn. pp. 155.

5. Cato, M.S. (2009). Green Economics: An Introduction to Theory; Policy and Practice, Earthscan, London.

6. Fayerweather, J. (2007). International Business Management. Thunderbird - International Business Review, vol 6, No 4.

7. Filipiak, B., Ruszala, J. (2009). Instytucje otoczenia biznesu. Rozwoj, wsparcie i instrumenty (Business Environment Institutions. Development, Support and Instruments), Difin, Warszawa.

8. Flak, O., Glod, G. (2009). Konkurencyjnosc przedsiebiorstwa. Pojecia, definicje, modele (The Competitiveness of the Company. Concepts, Definitions, Models). Uniwersytet Ekonomiczny w Katowicach, Katowice

9. Gorka, K., Luszczyk M. 2014. Zielona gospodarka i gospodarka oparta na wiedzy a rozwój trwały (Green Economy and Knowledge-Based Economy and Sustainable Development). Optimum. Studia Ekonomiczne 3(69), pp. 22-31.

10. Hwang, H., Powell, W. (2005). Institutions and Entrepreneurship, In "Handbook of Entrepreneurship Research, Disciplinary Perspectives", red. S. Alvarez, R. Agarwal, O. Sorenson, Springer

11. Jablonski, A., Jablonski, M. (2012). Zarzadzanie wartoscia regionu poprzez rozwoj i wzrost sektora małych i srednich przedsiebiorstw. Prognoza rozwoju sektora MSP w kontekscie rynku pracy. (Value Region Management by Developing and Growing the Sector of Small and Medium Enterprises. Development Forecast for the SME Sector in the Context of the Labor Market). Wyd. Grupa MARIS, Katowice.

12. Krupski, R., Niemczyk, J., Stanczyk-Hugiet, E. (2009). Koncepcje strategii organizacji "Concepts of Organization Strategy", PWE, Warszawa.

13. Kryk B. 2014. Czas na zielone kołnierzyki (Time for the Green Collar Workers), Ekonomia i Środowisko 3(50), pp. 10-20.

14. Limanski, A. (2015). Identyfikacja i strukturalizacja cech wspolczesnego otoczenia w zarzadzaniu przedsiebiorstwem. (Identification and Structuralization of the Features of Modern Environment in Enterprise) Acta Universitatis Nicolai Copernici. Zarzadzanie XLII(3), pp. 47-58.

15. North, D. (1990). Institutions, Institutional Changes and Economic Performance, Cambridge University Press, Cambridge

16. Ocampo, J. (2011). The Macroeconomics of the Green Economy. In "The Transition to a Green Economy", UNEP (2011), www.unep.org.

17. Otoczenie instytucjonalne malych i srednich przedsiebiorstw. (Institutional Environment of Small and Medium Enterprises" (1999). Red. R. Woodward. Wyd. CASE - Centrum Analiz Społeczno-Ekonomicznych, Warszawa.

18. Rachwal, T. (2008). Problematyka badawcza funkcjonowania przedsiebiorstw przemyslowych. (Research Problems Concerning the Functioning of Industrial Enterprises). Prace Komisji Geografii Przemyslu Polskiego Towarzystwa Geograficznego 11, pp. 53-85.

19. Ryszawska, B. (2013). Zielona gospodarka - teoretyczne podstawy koncepcji i pomiar jej wdrazania w Unii Europejskiej (Green Economy - Theoretical Grounds of the Concept and the Measure of its Implementation in the European Union). Wydawnictwo Uniwersytetu Ekonomicznego we Wroclawiu, Wroclaw.

20. Szyja, P. (2015). Zielona gospodarka w Polsce - stan obecny i perspektywy (Green Economy in Poland Current State and Perspectives). Nierownosci Spoleczne a Wzrost Gospodarczy 41(1), pp. 432-447.

21. Wach, K. (2008). Regionalne otoczenie małych i srednich przedsiebiorstw (The Regional Environment of Small and Medium Enterprises), Wydawnictwo Uniwersytetu Ekonomicznego w Krakowie, Krakow 
Proceedings of the 2018 International Conference "ECONOMIC SCIENCE FOR RURAL DEVELOPMENT" No 49

Jelgava, LLU ESAF, 911 May 2018, pp. 25-31

DOI 10.22616/ESRD.2018.114

22. Walczak, W. (2010). Analiza czynnikow wplywajacych na konkurencyjnosc przedsiebiorstw (Analysis of Factors Affecting the Competitiveness of Enterprises), E-mentor 5(37) http://www.ementor.edu.pl/artykul/index/numer/37/id/784. Access: 25.01.2018.

23. Wasilczuk, J.E. (2015). Otoczenie instytucjonalne a innowacyjnosc przedsiebiorstw (Institutional Environment and Innovativeness of Businesses). Zesz. Naukowe Uniwersytetu Szczecinskiego, Problemy Zarzadzania, Finansow i Marketingu 875(41)2, pp. 331-343. 